\title{
CSR, Tax and Development ${ }^{1}$
}

\author{
RHYS JENKINS \& PETER NEWELL*
}

\begin{abstract}
This article explores and critically examines the connections between tax and development on the one hand and tax and Corporate Social Responsibility (CSR) on the other. It does so because while there is increasing recognition of the importance of taxation to efforts to resource the state and finance efforts to tackle poverty, there is a surprising lack of attention to tax avoidance and evasion as a CSR issue for Transnational Corporations operating in the South, even among those companies that pride themselves on being CSR leaders. We review evidence of these trends, provide an empirical analysis of how leading firms deal with tax in their corporate reporting and make the case for including taxation as a new frontier in progressive CSR.
\end{abstract}

\section{Introduction}

Amid a series of scandals about the widespread use of tax avoidance schemes by leading Transnational Corporations (TNCs), including the non-payment of corporation tax in the UK by household brand names such as Google, Starbucks and Amazon, and parallel efforts by the development community to improve the tax raising capacities of states in the global south, the issue of corporate responsibility towards taxation has moved centre stage. But how serious a problem is it, what strategies do corporations employ to avoid paying tax and what can be done about it? What is the normative basis for including the 'beyond compliance' payment of taxes by TNCs to the growing list of other social and environmental issues that companies are expected to address as part of their Corporate Social Responsibility (CSR)?

TNCs have come under increasing pressure to enhance the developmental components of their CSR strategies when operating in the global south. ${ }^{2}$ Whether around labour rights, environmental protection or human rights issues, a range of initiatives have sought to harness the power of the private sector to alleviate poverty, either at a general level in the form of the Global Compact or the Sullivan Principles, or around specific issues such as the Extractive Industries Transparency Initiative or the Equator Principles on project financing. In historical terms this move dovetails with the emphasis within neo-liberalism upon the pivotal role of the private sector in development: an ideology promoted by a growing range of multilateral development banks and institutions of global economic governance and leading states in the international system which sponsor them. ${ }^{3}$ This mantle has been taken up by a number of development agencies which actively promote CSR as a way in which the private sector can contribute to development goals. ${ }^{4}$ Thus for the UK's Department for International Development (DFID): “By following socially

\footnotetext{
${ }^{*}$ Rhys Jenkins is at the School of International Development, University of East Anglia, Norwich NR4 7TJ r.o.jenkins@uea.ac.uk. Peter Newell is at the Department of International Relations, University of Sussex, Brighton BN1 9SN $\underline{\text { P.J.Newell@sussex.ac.uk }}$
} 
responsible practices, the growth generated by the private sector will be more inclusive, equitable and poverty reducing". Antonio Vives of the Inter-American Development Bank similarly writes that "CSR, by its very nature, is development done by the private sector, and it perfectly complements the development efforts of governments and multilateral development agencies". 6 Some have even gone as far as to trumpet the 'fortune at the bottom of the pyramid' available to those companies that target their products and services at the very poorest', in other words those that 'make poverty business'.

Besides the articulation of a 'business' case for addressing poverty, the uptake of CSR also responds to a legitimacy crisis provoked by public concern about acts of corporate irresponsibility in the global south including the exploitation of lower social or environmental standards and acts of negligence by allowing corporate leaders to allay demands for further regulation aimed at preventing a 'race to the bottom'. However corporate critics, including a number of development NGOs, ${ }^{9}$ have questioned whether CSR is as an appropriate means of promoting development. CSR is often seen as a form of public relations (referred to as "greenwash" in relation to environmental issues or bluewash when affiliations with the UN are sought through initiatives such as the Global Compact) designed to improve the image of companies but having little real development impact. ${ }^{10}$ Even well intentioned corporate efforts to promote development can have negative impacts because of lack of understanding of local contexts. ${ }^{11}$ The CSR agenda is often shaped by pressures from NGOs, trade unions or consumers in the North and as a result the issues addressed reflect their concerns rather than the development needs of claimed beneficiaries in the global South. ${ }^{12}$ Moreover, many of the negative impacts associated with business are a result of corporate strategies which are crucial for the profitability of the companies concerned but which are left untouched by CSR, such as the ability to rapidly re-locate capital, informal labour contracts, outsourcing and lack of trade union recognition. ${ }^{13}$

This paper focuses on one of the issues which have been largely absent from the CSR agenda: tax payments and tax avoidance by companies. This is despite a flurry of recent scandals engulfing leading corporations that identify themselves as leaders on CSR issues. The next section considers in more detail the development of the CSR agenda and the limitations of CSR as a means of promoting development in general. The paper then turns to the role of taxation in development and the increasing attention given to the need for a capable state and the role of taxation in ensuring that the state is able to support the private sector. ${ }^{14}$ This is followed by a discussion of the evidence on tax evasion and tax avoidance and the impact that this has on government revenues in developing countries. It will also provide evidence of the prevalence of such practices amongst major TNCs. A case is then made for regarding corporate tax strategies as an integral part of CSR. Indeed there are many parallels between tax and mainstream CSR issues such as labour rights and environmental sustainability. However, as Section 6 shows where we provide an analysis of the leading 35 companies listed on the FTSE4Good, most major companies do not currently regard tax as an aspect of CSR. The paper concludes with a discussion of the requirements of a responsible corporate tax policy and also of the limitations of CSR as a means of tackling tax problems. 


\section{CSR and Development}

The wave of CSR aimed at pacifying concerns about the ability of TNCs to exploit double (lower) standards when operating in the developing countries led to a proliferation of corporate codes of conduct and CSR reports as well as a variety of international initiatives including those mentioned above. It dates back to the 1990s culminating in the establishment of the UN Global Compact in 2000. This followed a period of deregulation and increased openness in most developing countries as a result of the structural adjustment policies adopted in the 1980s. Growing reliance on foreign direct investment (FDI) and the increased involvement of Northern buyers in global "value chains" led to deeper integration between developed and developing countries. ${ }^{15}$ At the same time, the increased significance of brands and corporate reputation rendered leading companies particularly vulnerable to bad publicity. The developments in global communications which enabled corporations to control production activities on an ever-widening scale also facilitated the international transmission of information about working conditions at overseas suppliers, contributing to increased public awareness and facilitating campaigning activities. ${ }^{16}$

Companies often responded to bad publicity surrounding their activities by adopting CSR strategies. Many firms sourcing consumer goods from developing countries put in place supplier codes of conduct following scandals about the labour practices of their subcontractors. ${ }^{17}$ Environmental issues also became a matter of increasing public concern, as attention focused on the Earth Summit held in Rio in 1992. In the run-up to that Summit, the corporate sector resisted suggestions that legally-binding environmental rules should be applied to transnational corporations, instead promoting self-regulation through voluntary codes and charters. ${ }^{18}$ During the 1990 s, major transnational corporations in the oil and other extractive industries, such as Shell, BP and Rio Tinto came to be seen as leaders in terms of the environmental dimensions of CSR. They also incorporated the protection of human rights into their business principles, following the negative publicity about Shell's activities in the Niger Delta and BP's operations in Colombia in the mid1990s. ${ }^{19}$

The emergence of the environmental impacts of business, labour rights and human rights as central issues in CSR in recent years largely reflects the particular concerns of NGOs, trade unions, consumers and shareholders in the developed world. ${ }^{20}$ Even within these broad areas, the particular issues that have attracted most attention are often those which appeal to these Northern stakeholders. This is no doubt partly why eliminating child labour has been such a focus in relation to labour rights. ${ }^{21}$ Companies are particularly concerned with those aspects of their operations which can potentially damage their reputation as a result of media exposure. Other issues have been largely absent from the CSR agenda up to now, including aspects of corporate behaviour such as abuse of market power, transfer pricing and tax avoidance.

One of the main limitations of CSR is the way in which corporate practices that are central to company profitability are not considered part of a company's corporate 
responsibility. One example of this is the purchasing practices of buyers in garment and horticulture supply chains where rapid response and tight delivery schedules are the rule. $^{22}$ This often leads to long hours of work, compulsory overtime and the cancellation of rest days, which go against the companies' aspirations to social responsibility as set out in their codes of conduct. Since these practices are seen as crucial for competitiveness, they are allowed to continue while CSR initiatives focus on issues such as avoiding employment of under-age workers which in situations where there is an ample supply of labour, does not pose such a problem.

One issue which has not, so far, featured prominently on the CSR and development agenda is taxation. Although issues of corporate tax avoidance have come to the fore in the North during the global financial crisis and some development NGOs have raised the issue of tax avoidance by transnational corporations (TNCs) in developing countries ${ }^{23}$ as will be shown below, it has barely been touched upon in the discussion of CSR in developing countries.

\section{Tax and Development}

The space that has been opened up, post-Washington Consensus, for the re-evaluation of the role of the state in development has enabled a focus on issues of governance and the need for an effective state. This has led to an emphasis on the need for adequate finance and more specifically to a focus on taxation and development. ${ }^{24}$ The UN International Conference on Financing for Development, held in Monterrey, Mexico in 2002 emphasized the need to enhance the revenue-raising capacities of developing countries as a crucial factor in advancing sustainable development. More recently, a joint meeting of the OECD Development Assistance Committee and the Committee on Fiscal Affairs stated that "a strong tax system is at the heart of a country's financial independence, its revenues are the lifeblood of the state itself". ${ }^{25}$

At the same time, globalisation has made it increasingly difficult for states to obtain tax revenues. The increased mobility of capital and spread of global operations of major companies has opened up new possibilities for both tax avoidance and evasion. The vast sums being channelled through tax havens offer a clear indication of the problems faced by governments in protecting their revenue base. ${ }^{26}$ Moreover, increased competition between countries to attract FDI leads to more generous incentives and tax breaks being offered to multinationals. It is not surprising in this context that many states face large and growing fiscal deficits.

This is a particular problem for developing countries. First, they tend to rely more heavily on corporate taxes than developed countries. The average share of corporate taxes in total tax revenue between 1990 and 2001 was $17 \%$ as opposed to $7 \% .{ }^{27}$ Second, corporate tax revenue declined more rapidly in developing counties. There is a real danger that developing countries get caught in a vicious circle. Declining tax revenues weakens the state just as it is increasingly recognised that development, even if led by the private sector, requires an efficient and well financed state. The weakening of the state in turn makes it less able to take the steps necessary in order to strengthen its fiscal position. Is 
there an alternative which will make it possible for developing countries to rebuild their fiscal position?

\section{Corporate Tax Strategies and Government Revenue}

While the need for tax revenue is widely recognised, the ability of governments to raise taxes in developing countries is limited. On average tax revenues accounted for $35 \%$ of GDP in developed countries, but only $15 \%$ in developing countries and $12 \%$ in low income countries in $2005 .{ }^{28}$ Low tax revenues are partly a reflection of the extent of the informal sector which it is difficult by its very nature to tax (the domestic component) and partly a result of tax evasion and tax avoidance by corporations in the formal sector and wealthy individuals who are able to shift profits and hold assets overseas. It is this latter international component and particularly that associated with the activities of transnational corporations that are of interest in this paper.

In a world where capital is increasingly mobile and globally organised, whereas taxes are raised at a national level, the opportunities that companies have to reduce their tax payments are many. Indeed some of the changes in the global economy which were seen above to have contributed to increased pressures on companies to adopt CSR, have also made it easier for them to reduce their tax liabilities. The growing importance of intangible assets such as brands as a source of profit has made it possible for companies to locate assets in low tax areas without having to establish a significant physical presence, as a result of what Palan refers to as the 'commercialisation of sovereignty'. The speed and low cost of global communications has also facilitated the dispersal of corporate assets around the world to take advantage of tax differentials. This has been accompanied by a change in the attitude of corporations towards tax compliance over the past couple of decades where it has come to be seen by some as discretionary rather than obligatory and the growth of the "tax shelter" industry actively promoted by major accountancy firms. ${ }^{30}$ The large numbers of tax havens around the world and the volume of transactions that pass through them, is perhaps the most striking illustration of the importance both companies and wealthy individuals attach to reducing their tax bills. ${ }^{31}$

\section{Tax evasion, tax avoidance and tax compliance}

A distinction is usually made between tax evasion which is illegal and tax avoidance which is not. Tax evasion involves deliberate deception of the tax authorities through, for example, not declaring income for tax purposes, false accounting or false invoicing on traded goods. Tax avoidance on the other hand refers to measures to minimize a tax bill while complying with the letter of the law. This can be achieved through a variety of complex pricing and financial transactions and corporate structures. The distinction is not as clear cut as might appear though since an arrangement that a company considers legal may, if challenged in court by the tax authorities, be found to be illegal. Indeed HMRC's Anti-Avoidance Group states that "It is impossible to provide a comprehensive definition of ( $\operatorname{tax}$ ) avoidance". ${ }^{32}$ 
A distinction is also drawn between tax avoidance and tax planning. Since tax incentives are often provided by governments to induce certain types of behaviour by companies, responding to such incentives is not regarded as tax avoidance, although it reduces the company's tax payments. Again this distinction is not clear cut. HMRC indicates that:

"Fine distinctions between 'tax planning' and 'tax avoidance' are seen as being of less consequence than the overall effect on the yield to the Exchequer". ${ }^{33}$

The Tax Justice Network provides the following definition of tax avoidance:

"Aggressive tax avoidance is the practice of seeking to minimise a tax bill by attempting to comply with the letter of the law whilst avoiding its purpose or spirit. It usually entails setting up artificial transactions or entities to re-characterise the nature, recipient or timing of payments". 34

A similar definition which again emphasises the artificial nature of transactions is provided by The Guardian newspaper which describes tax avoidance as:

"Artificial schemes that try to take advantage of loopholes or lack of clarity in the law to reduce a company's tax bill, or deliberate structuring of ownership of assets (particularly in relation to location) to reduce tax". ${ }^{35}$

Some authors present corporate tax strategies as a continuum which goes from tax evasion through more or less "aggressive" tax avoidance to tax compliance. Such an approach has the advantage of avoiding hard and fast distinctions which, as pointed out above, are sometimes difficult to make.

\section{Estimates of tax avoidance in developing countries}

By its very nature, the extent of tax evasion and tax avoidance is very difficult to measure. Although there are some official figures for the "tax gap" in developed countries, most of the estimates that have been made for developing countries come from NGOs.

Table 1 shows a number of estimates of the total amount of tax lost by developing countries which have been widely quoted. A variety of different approaches have been used to arrive at these figures. Most studies of illicit capital flows and the associated loss of tax revenues are based either on analysis of trade data to try to identify mispricing of transactions which leads to profit shifting, or on an analysis of declared profit rates in jurisdictions with different tax rates. Trade studies either look at discrepancies in reported trade values between importers and exporters which could reflect double-invoicing of transactions, or large deviations in the prices of similar goods recorded.

\section{Table 1: Estimates of Tax Revenue Lost by Developing Countries through Corporate Tax Avoidance ${ }^{36}$}




\begin{tabular}{|l|l|}
\hline Study & Tax Revenue Lost \\
\hline Cobham (2005) & $\$ 50$ bn. \\
\hline Christian Aid (2008) & $\$ 160$ bn.(2008) \\
\hline Christian Aid (2009) & $\$ 121.8$ bn. (avge. $2005-7)$ \\
\hline Oxfam (2000) & $\$ 35$ bn. (1998) \\
\hline Hollingshead, (2010) & $\$ 98-106$ bn. (avge. $2002-2006)$ \\
\hline
\end{tabular}

Critics have questioned the methods that have been used to arrive at these estimates and the strong assumptions on which they are based. ${ }^{37}$ Fuest and Riedel in their survey conclude that "most existing estimates of tax revenue losses in developing countries due to evasion and avoidance are not based on reliable methods and data". ${ }^{38}$ However others, while not denying the crude nature of many estimates, argue that there is evidence that developing country governments are losing tax revenues as a result of corporate practices and that the orders of magnitude quoted are not implausible. ${ }^{39}$

Further support for the view that corporate tax avoidance is not a trivial problem comes from estimates in developed countries where data and methods are more reliable. These also show substantial tax losses even though the tax authorities are much better resourced than in developing countries. Studies for the US have arrived at estimates of tax losses of between $\$ 10$ billion and $\$ 60$ billion $^{40}$ while in the UK the Trade Union Congress (TUC) ${ }^{41}$ estimated losses through corporate tax avoidance of $£ 12 \mathrm{bn}$. a year. ${ }^{42}$ Given the much greater capacity of the tax authorities in the North to monitor and control such practices compared to their counterparts in the South, this reinforces the impression that developing countries may lose substantial amounts of government revenue through tax evasion and avoidance.

\section{Mechanisms for Tax Avoidance}

There are a number of ways in which companies practice tax avoidance. These can be grouped into three broad categories. ${ }^{43}$ First, there is the manipulation of the prices of goods and services charged internally within the firm. Second, firms can arrange their corporate structure and ownership of assets in ways that reduce their tax liabilities. Finally, there are alternative financing arrangements which can be used to gain maximum tax benefit. ${ }^{44}$

TNCs which have activities in a number of different tax jurisdictions can reduce taxes by pricing transactions between different affiliates in such a way that profits are declared in those countries where tax rates are lowest. In the USA, it has been reported that $48 \%$ of exports and $40 \%$ of imports involve trade between related parties. ${ }^{45}$ Globally it is estimated that a third of world trade is intra-firm. ${ }^{46}$ This shows that the scope for using transfer pricing to shift profits is considerable. The prices of exports can be inflated in low tax countries and artificially lowered in high tax countries, with the reverse happening for imports.

Most of the studies of transfer pricing manipulation come from developed countries, particularly the US. ${ }^{47}$ The Internal Revenue Service (IRS) has also been active in 
pursuing companies which it believes have been artificially reducing their declared profits through such practices. ${ }^{48}$ Summarizing a number of recent cases Sikka and Willmott concluded that "transfer pricing is not just an accounting technique, but also a method of resource allocation and avoidance of taxes that affects distribution of income, wealth, risks and quality of life." 49

The use of transfer pricing as a means of transferring resources out of developing countries was first brought to light by a study carried out in Colombia in the 1970s. ${ }^{50}$ Subsequent studies in other Latin American countries, and in India, Iran and Greece revealed that this was by no means an isolated example. ${ }^{51}$ More recently a series of studies of firms operating in China have found extensive evidence of transfer price manipulation $^{52}$ In 2011 the Argentine revenues and custom service was moved to bring charges against some of the world's largest grain traders such as Cargill, ADM and Bunge for allegedly inflating costs in Argentina to reduce taxable profits as well as using subsidiaries in Uruguay and Switzerland to evade taxes in Argentina for which the government claims it is owed $£ 290$ million in unpaid tax and duties. ${ }^{53}$ One recent study of trade mispricing estimated that developing countries lost an average of around $\$ 100$ billion a year in tax revenue as a result between 2006 and $2010 .^{54}$

The studies of transfer pricing have focussed primarily on transactions in goods where there is a possibility or estimating "arm's length" prices at which trade between unrelated parties would take place. It is much more difficult to detect mispricing where the transactions involve intellectual property or intangibles. The royalty payments made for the use of a particular innovation by a subsidiary may have no arm's length transaction with which it can be compared. One study of the USA suggested that about a half of all income shifting was due to transfer pricing of intangibles. ${ }^{55}$

While transfer pricing can involve real transactions and the tax advantage to the company comes from manipulating the prices charged, it is also possible to reduce tax liabilities by altering corporate structures and creating artificial transactions. This often involves creating subsidiaries in tax havens where the company simply engages in paper transactions. The world's major banana transnationals, Dole, Chiquita, Del Monte and Fyffes have subsidiaries in a number of tax havens and low tax countries such as the Cayman Islands, Bermuda, Ireland, Jersey and the Isle of Man, which charge the parent companies for using its brands, purchasing network, distribution services, management expertise and legal services. As a result only a small part of the total profit on bananas is declared in either the producing countries in Latin America or the final destination in the US or UK. ${ }^{56}$ Another example is the iconic scallop logo of Shell which is owned by a subsidiary in the low tax Swiss canton of Zug. This subsidiary then charges a royalty for the use of the logo by other Shell companies. ${ }^{57}$ Another transnational company, SAB Miller, is alleged by Action Aid to shift substantial sums of profit from its Ghanaian subsidiary, Accra Breweries, through royalty payments and management fees to group companies in the Netherlands and Switzerland where tax rates are much lower. ${ }^{58}$ Action Aid also claims that Associated British Foods' (ABF) subsidiary Zambian Sugar plc has reduced its tax liabilities in Zambia through payments of fees to ABF subsidiaries in Ireland and Mauritius. ${ }^{59}$ 
Parent companies can change their country of incorporation or where they nominally have their headquarters to take advantage of lower tax rates as a number of UK based companies did by switching to Dublin in 2008. ${ }^{60}$ In the same year Boots the Chemist moved its headquarters from Nottingham to the Swiss canton of Zug. ${ }^{61}$ Companies also set up holding companies in low tax countries which own subsidiaries in other higher tax countries. Companies can also reduce their tax obligations through a scheme known as "outward domestication" which involve the transfer or sale of assets within a corporate group. ${ }^{62}$ This was used by the UK parent company Diageo Plc to transfer ownership of its Johnny Walker brand to a Dutch subsidiary without having to pay any tax on the sale. Although the whiskey continued to be made in Scotland, much of the profit now goes abroad. $^{63}$

A third major area in which firms can reduce their tax bills is through complex financing arrangements. This can arise from the different treatment accorded to share capital and loan capital by tax authorities. Whereas share capital receives dividends from post-tax profits, interest is regarded as a cost and deducted from the paying company's profits for tax purposes. ${ }^{64}$ This creates an incentive for "thin capitalisation" where a subsidiary is financed with a large proportion of loans rather than shares and the interest paid to another subsidiary in a low tax area thus reducing the total tax paid by the corporation. ${ }^{65}$ An example of this practice was Exxon's Disputada de Las Condes copper mine in Chile which apparently operated at a loss during the 1980s and 1990s. It was heavily indebted to Exxon Financials, a Bermuda-based financial branch, to which it paid interest. As a result the interest payments made were subject to a Chilean tax of only $4 \%$ as opposed to the $35 \%$ tax that would have been applied to profit remittances. ${ }^{66}$ SAB Miller used a similar strategy of thin capitalisation in Ghana, where Accra Breweries received a substantial loan of more than seven times its capital from Mubex, a SAB Miller subsidiary in Mauritius, another tax haven. ${ }^{67}$

The existence of the practices described above is by no means confined to developing countries as the recent revelations about Starbuck's activities in the UK make clear. ${ }^{68}$ However, the problems tend to be particularly acute for developing countries because of their relatively smaller tax base and limited capacity to detect and prevent such practices. $^{69}$

\section{Should CSR address Tax Issues?}

It is only relatively recently that the literature on CSR has begun to address issues of tax strategy. ${ }^{70}$ However, it is likely to become an increasingly important item on the CSR agenda in the foreseeable future. In 2004 the director of the OECD tax policy centre suggested that "tax is where the environment was 10 years ago"." Although this statement now seems a little premature, it is possible to draw parallels with the developments that led to the wave of CSR related to environmental and labour rights' issues in the $1990 \mathrm{~s}$, described earlier. ${ }^{72}$ 
There are clear indications of increasing concerns within civil society over corporate tax avoidance. It features centrally in the 'If' campaign coordinated by over 100 development charities which claims, "IF governments close tax loopholes to ensure companies pay their fair share of taxes in poor countries, millions of children will not have to go hungry". ${ }^{73}$ Over the past decade both specialist NGOs such as the Tax Justice Network in the UK and Global Financial Integrity in the US, development NGOs such as Oxfam, Action Aid and Christian Aid and groups protesting public sector cuts such as Un-Cut in the UK have begun to campaign around the issue of tax avoidance by transnational corporations. Particularly since the global financial crisis of 2008 led to increased fiscal deficits in the developed world and government adoption of austerity measures involving large cuts in government expenditure, the media has "named and shamed" companies which are seen not to be contributing their fair share of taxes ${ }^{74}$ the payment of which could forego the need for some cuts, much in the same way as they exposed violations of labour rights by suppliers of major retailers and brands in the past. Governments and international organisations have also given more attention to issues of tax avoidance, particularly in relation to the use of tax havens. ${ }^{75}$ In the UK, the Chancellor, George Osborne condemned "aggressive tax avoidance", ${ }^{76}$ while Prime Minister David Cameron called for international action on tax avoidance in his speech at the World Economic Forum in Davos in January 2013. ${ }^{77}$

A number of strands of CSR discourse suggest that tax issues could legitimately be included within the scope of CSR. ${ }^{78}$ The notion of corporate citizenship is often used in this context to describe the range of responsibilities a corporation has towards the society in which it operates. Arguably taxation is part of the "social contract" between the citizen and the state thus generating an obligation on the part of citizens to contribute. A claim to "corporate citizenship" can therefore be held to generate an obligation to pay tax in the jurisdiction within which the firm is operating. Yet currently while a bank such as Barclays refers to itself as a responsible global citizen and operates a reputation committee as well as a range of CSR initiatives, 'nowhere does its policy mention Barclays' tax avoidance schemes'. ${ }^{79}$

A second argument for regarding tax as a CSR issue is the latter's emphasis on the need to take into consideration the interests of stakeholders as well as the narrow interests of shareholders. Whereas from a shareholder perspective, taxation is a cost to be minimized (as too are wages), from a stakeholder perspective, taxes and wages are part of the total value produced and thus the state is as much a stakeholder in the enterprise as the employees.

Alternatively, it could be argued that the state could be seen as supplying services to the private sector, whether in the form of an educated labour force, the legal system or roads which the company uses to transport its goods. Taxation is then the price which a company pays in return for these services and since CSR includes "fair dealing with suppliers", ${ }^{80}$ paying taxes is part of fair dealing with the state as a supplier. Sikka puts this in terms of the state providing "social capital" for the private sector, in the same way as shareholders provide financial capital. ${ }^{81}$ 
Perhaps one of the most common formulations of CSR is in terms of the need for a company to consider its Triple Bottom Line including its social and environmental as well as its conventional economic impacts. ${ }^{82}$ In this context taxation can be seen as contributing to the Triple Bottom Line. For some, although it is not part of the company's financial return, it should be included in the economic bottom line. ${ }^{83}$ Others, however, see it mainly contributing to the social bottom line. ${ }^{84}$ Either way, there is a clear case for regarding tax payments as something more than just a cost to be minimized.

The argument often put by those who defend tax avoidance (as opposed to illegal tax evasion) is that no company (or individual) is under any obligation to pay more than the minimum tax which they are legally required to pay and that it is legitimate business practice to arrange your affairs in such a way as to minimize tax payments within the law. Indeed, responsibilities to shareholders might imply that a corporation would be behaving irresponsibly if it paid more tax than was required of it by law. Eric Schmidt, Chairman of Google, when challenged about the company's tax avoidance strategies stated bluntly: 'I am very proud of the structure that we set up. We did it based on the incentives that the governments offered us to operate. It's called capitalism. ${ }^{85} \mathrm{CSR}$ often emphasises "going beyond compliance", however. Particularly in developing countries where laws are weak or standards low, mere compliance cannot be used to claim a high standard of corporate responsibility. Equally then, a claim to being a socially responsible company requires something more than avoiding illegal tax evasion while making use of all available tax loopholes.

Finally, it can be argued that exactly the same kind of "business case" for addressing tax issues exists as are often put forward more generally for adopting CSR. ${ }^{86}$ These include:

- the reputational risk that can come from negative publicity if the company is shown to be avoiding tax;

- the risk of litigation and fines if tax strategies are challenged by the tax authorities;

- the risk of jeopardizing relations with governments and potential negative impacts when bidding for government contracts;

- uncertainty about future tax liabilities having a negative effect on shareholder value;

- $\quad$ pre-empting the risk that tax rules will be tightened.

This suggests that there are strong reasons why tax strategy should be addressed as an aspect of CSR. With growing public concern over tax avoidance, failure to do so could potentially undermine corporate legitimacy.

\section{CSR and Taxation in Practice}

Although a strong case can be made that companies espousing CSR should address tax issues, in practice they are rarely mentioned either in CSR reports or corporate codes of conduct. As the examples mentioned earlier illustrate, tax avoidance is practised by many leading transnational companies. ${ }^{87}$ Many of these companies are also regarded as leaders 
in terms of corporate social responsibility, have ethical codes of conduct and publish CSR reports. Indeed, the apparent disconnect between the high sounding rhetoric of corporate claims of social responsibility and their everyday practices in terms of tax strategy has been characterized recently as "organized hypocrisy". ${ }^{88}$

Although Sikka focuses on a supposed double standard between what companies say and what they do in practice, in fact none of the CSR statements that he quotes from the companies that he analyses explicitly mention tax. Indeed, one of the most striking aspects of the debate about CSR and taxation is that although various organizations ${ }^{89}$ have pushed for a link to be established, most firms do not make one.

Previous studies of the content of codes of conduct show that these very rarely mention tax issues. An OECD survey of 233 codes by individual companies, industry and trade associations, partnerships of stakeholders and inter-governmental organizations found that taxation was only mentioned in one code..$^{90}$ Similarly, a study of the codes of the 200 largest companies in the world found that timely payment of taxes was only mentioned by one company. ${ }^{91}$ More recently, a study comparing the codes of conduct of 26 companies headquartered in tax havens and 20 US based firms found only one firm in each group referring to tax payments in their codes of conduct. In both cases this was merely a commitment to comply with tax rules and legal obligations. ${ }^{92}$

Even companies that are regarded as leaders in terms of CSR rarely give any attention to taxation as a CSR issue. As a part of this research a survey of the CSR reports and codes of conduct of major TNCs regarded as CSR leaders was carried out in 2010. Of the top 100 TNCs according to UNCTAD's World Investment Report, 35 were listed on FTSE4Good. In our survey these 35 were taken as examples of leaders in terms of CSR and their CSR reports and their codes of conduct examined to see what they had to say about tax.

Only in 13 cases was there any mention of tax in the CSR report and the majority simply refer to the fact that they make a contribution to the countries in which they operate through paying taxes and make no explicit mention of their corporate tax policies. Only four of the companies made some explicit statement related to the company's tax policies - Diageo, WPP, Repsol-YPF and Telefónica. ${ }^{93}$ Diageo states that "Transactions between Diageo subsidiaries based in different countries are priced on an arm's length basis as if the subsidiaries were unrelated companies, in accordance with the OECD Model Tax Convention". ${ }^{94}$ WPP indicate that "We believe our obligation is to pay the amount of tax legally due in the territory in which the liability arises and to observe all applicable rules and regulations in all the territories in which we operate. However, at the same time we also have an obligation to maximise share owner value and to manage financial and reputational risk. This includes controlling our overall liability to taxation." ${ }^{\text {95 }}$ RepsolYPF claims transparency in tax payments in accordance with the Extractive Industry Transparency Initiative, while Telefónica explicitly states that it does not use tax havens in its operations. 
Even fewer companies referred to tax issues in their codes of conduct than in their CSR reports - nine in total. Most of these cases refer to the need to comply with the law and to pay a fair share of taxation. However they also often mention the need to minimize taxation in the interest of shareholder value. Vodafone for examples states that it "is not able to determine the 'fair' amount of tax for it to pay overall, or in any particular territory. It believes its obligation is to pay the amount of tax legally due in any territory, in accordance with rules set by governments. The maximisation of shareholder value will generally involve minimisation of taxation". ${ }^{96}$ Similarly Unilever declares that "Our Code of Business Principles requires all Unilever companies to comply with the laws and regulations of the countries in which they operated, and this applies just as much to taxation as to any other issue ... in order to create and preserve value, we will seek to minimise our tax liabilities while complying with all applicable laws." ${ }^{97}$

Some codes also refer to steps to influence government tax policies. Thus Vodafone will "Where possible and appropriate (seek) to shape future tax legislation and practice in ways that promote the Group's interest". Unilever makes a similar statement to the effect that "Our Code also encourages our businesses to represent their views on the formulation and administration of tax laws, either directly or through trade associations and similar bodies". 98

This indicates that very few companies see their tax strategies as being in any way related to their CSR activities. They are happy to claim that they are making a social contribution through paying taxes that are legally due. However, they do not generally make any commitments in terms of tax avoidance and even where they do mention these issues, they tend to be qualified by reference to the interest of shareholders or the group. Recent public concern about tax avoidance may be making some companies more circumspect in their statements on tax policies, but the issue is still not generally seen as an aspect of CSR.

\section{What would a responsible tax strategy involve?}

This raises the question of what would be the key elements of corporate responsibility in relation to taxation. While it is not the aim here to develop a fully fledged strategy, it is worth identifying a few key features that would need to be included.

As was seen earlier, the use of transfer pricing has been a key way in which global companies have reduced their tax bills. A first step, therefore, would be to commit to using arm's length pricing in all transactions with related parties as recommended by the OECD Guidelines on Multinational Enterprises. While it is not always easy to establish arm's length prices for all transactions, there are principles laid out by the OECD in its Transfer Pricing Guidelines for Multinational Enterprises and Tax Administrations which are regularly updated.

A second mechanism identified which enables companies to avoid taxes is through the creation of complex corporate structures and the allocation of assets within those structures. Here a fundamental commitment would be to avoid the artificial creation of 
such structures that are unrelated to real business transactions and are primarily created to reduce the tax liabilities of the corporation. Since many of these artificial structures which companies use involve subsidiaries located in tax havens, a commitment along the lines made by Teléfonica, as mentioned above, to avoid using tax havens in their operations would be a further indication of a responsible tax policy.

The third mechanism that was identified earlier through which companies seek to avoid tax is through artificial financial arrangements. Again, there should be a commitment not to use such arrangements in order to reduce the company's tax burden, unless there was a non-tax related reason for doing so.

A responsible tax strategy involves not only taking steps to ensure that the company does not engage in tax avoidance, but also requires a high level of transparency. This includes both transparency in payments that are made, as is required, for example, by the Extractive Industries Transparency Initiative, but could be extended to reporting on a country-by-country basis.

Tax avoidance is not the only negative aspect of corporate behaviour that affects government fiscal revenues. The pressure to reduce tax rates in order to attract investment which governments are often subject to from multilateral development institutions, and the broader context of "tax competition" between countries, also undermine the ability of governments to obtain adequate fiscal resources. Contrary to current practices, corporate responsibility would involve a company agreeing not to lobby or pressure host governments to provide it with more favourable tax treatment. This might be consistent with the increasing emphasis within CSR on 'responsible lobbying'. 99

There are of course limitations to the use of CSR as a means of dealing with tax avoidance. Many of these are similar to those which have been noted in relation to other aspects of CSR. First of all, where particular strategies are central for a company's profitability, then it is particularly difficult to change in order to bring practice into line with the rhetoric. Companies which at present make extensive use of tax avoidance and have large numbers of subsidiaries located in tax havens may find altering their strategies particularly costly. As with all voluntary codes, the failure of some companies to add such standards creates a "free rider" problem with laggards who continue to practice tax avoidance gaining a competitive advantage vis-à-vis those companies which adopt more stringent standards. Restraint in terms of not exploiting loop-holes, even where legally it might be permissible to do so, would need to be exercised by leading TNCs to show the way and generate pressure on others to conform.

The fact that public pressure puts some companies in the spotlight more than others, means that the application of voluntary measures tends to be uneven. Most of the companies whose tax avoidance strategies have attracted widespread attention have tended to be those supplying consumer goods and having a direct relationship with the public. Reliance on pressure from civil society to promote greater tax payments also depends on the activities of NGOs who are constrained by their limited resources and campaigning priorities and therefore tend to focus on a few high profile companies. ${ }^{100}$ 
This implies that a regulatory approach is required in order to ensure compliance across the board.

\section{Conclusion}

This paper has shown that tax avoidance by transnational corporations is a major global issue, particularly for developing countries where the tax base is relatively weak and the capacity of the state to effectively control such practices is very limited. The fiscal crisis of both developed and developing countries has put tax avoidance more firmly on the agenda than ever before.

Although leading companies claim to be socially responsible, the focus of their CSR efforts up to now has been on environmental, labour and human rights issues and taxation has rarely featured. Indeed, many TNCs see no contradiction in espousing CSR while at the same time seeking to minimize their tax liabilities, often through aggressive tax avoidance. They are facilitated in doing so by the absence of tax issues from the CSR agenda.

In the wake of the global financial crisis, the climate of opinion is changing and civil society organizations are putting increasing pressure on companies over their tax contributions. It is likely therefore that taxation will come to be seen increasingly as an issue which companies need to address as part of their CSR. In addition to the external pressure that companies will face, there are a number of reasons why logically, CSR should include commitments on tax. We have proposed some key elements of a responsible tax strategy.

We do not believe that the inclusion of commitments on tax will remove the problem of tax avoidance any more than environmental or labour rights' issues can be dealt with solely by voluntary corporate commitments. Measures to strengthen the capacity of the state in developing countries and international action, for example to restrict the use of tax havens, will also be necessary. Greater cooperation between national tax authorities and requirements by home countries for greater transparency in reporting by TNCs is also needed. However, companies that claim a high level of social responsibility should not stand by and wait for governments and international organizations to take a lead, but should lead the way in terms of country-by-country reporting and abandoning transfer price manipulation and the use of tax havens. Failure to do so could in the future undermine their legitimacy in the same way that abuse of workers or environmental disasters has affected companies in the past. 

${ }^{1}$ We would like to express our gratitude to the reviewers and editor at Third World Quarterly, to Matt Cape for research assistance on
this project and to the ESRC for support for a workshop on this theme as part of the series 'Corporate responsibility and human development' (RES-451-26-0548).

${ }^{2}$ Rhys Jenkins, 2005, 'Globalization, Corporate Social Responsibility and Poverty', International Affairs, 81 (3) 2005, pp.525-540.

${ }^{3}$ Deborah Eade \& John Sayer, Development and the Private Sector, Bloomfield CT: Kumarian Press, 2005.

${ }^{4}$ Unleashing Entrepreneurship: Making Business Work for the Poor, New York: UNDP, 2004

${ }^{5}$ DFID, SociallyResponsible Business Team strategy: April 2001-March 2004, London: Department for International Development, p.2.

${ }^{6}$ A. Vivos, 'The role of multilateral development institutions in fostering corporate social responsibility' Development 47 (3) 2004), p.46

${ }^{7}$ CK Prahalad \& SL Hart, 'The fortune at the bottom of the pyramid', Strategy \& Business, 26, 2002,

pp $2-14$; CK Prahalad \& A Hammond, 'Serving the world's poor, profitably', Harvard Business

Review, 80 (9), 2002, pp 48 - 57; and CK Prahalad, The Fortune at the Bottom of the Pyramid-

Eradicating Poverty Through Profits, Upper Saddle River, NJ: Wharton School Publishing, 2005.

${ }^{8}$ Craig Wilson \& Peter Wilson, Make Poverty Business: Increase Profits and Reduce Risks by Engaging

with the Poor, Sheffield: Greenleaf Publishing, 2006; M Blowfield \& G Frynas, 'Setting new agendas: critical perspectives on Corporate Social Responsibility in the developing world", International Affairs, 81(3), 2005, pp. 499-513.

${ }^{9}$ Christian Aid, Behind the Mask: the real face of corporate responsibility, London: Christian Aid 2004; Oxfam, Trading away our rights: Women working in global supply chains, Oxford: Oxfam International 2004.

${ }^{10}$ Ann Zammit, Development at Risk: Rethinking UN-Business Partnerships, South Centre and UNRISD, 2003, Joshua Karliner, The Corporate Planet: Ecology and Politics in the Age of Globalization. San Francisco, CA: Sierra Club Books, 1997.

${ }^{11}$ Frynas, J.G., 2009, Beyond CSR: Oil Multinationals and Social Challenges Cambridge: CUP

${ }^{12}$ Marina Prieto-Carron, Peter Lund-Thomsen, Anita Chan, Ana Muro \& Chandra Bhushan, 'Critical perspectives on CSR and development: what we know, what we don't know and what we need to know', International Affairs, 82 (5), 2006, pp. 977 - 987.

${ }^{13}$ Peter Newell and Jedrzej. G. Frynas Beyond CSR? Business, poverty and social justice. Third World Quarterly 28(4), 2007, pp. 669-681.

${ }^{14}$ D Brautigam, O.H. Fjeldstad and M Moore (2008) Taxation and State-Building in Developing Countries: Capacity and Consent. Cambridge: Cambridge University Press.

${ }^{15}$ Raphie Kaplinsky, Globalization, Poverty and Inequality, Polity Press, 2005.

${ }^{16}$ Peter Newell, 'Managing multinationals: the governance of investment for the environment', Journal of International Development 13(7), 2001, pp. 907-919.

${ }^{17}$ Rhys Jenkins, Ruth Pearson \& Gill Seyfang (eds.) Corporate Responsibility and Labour Rights: Codes of Conduct in the Global Economy. London: Earthscan, 2002.

${ }^{18}$ Stephen Schmidheiny, Changing Course. Cambridge, MA: MIT Press, 1992.

${ }^{19}$ Frynas, Beyond CSR

${ }^{20}$ Jem Bendell, Barricades and boardrooms: a contemporary history of the corporate accountability movement, Technology Business and Society Paper 13, Geneva: UNRISD, 2004; Rhys Jenkins, Corporate codes of counduct: self-regulation in a global economy, Technology, Business and Society Paper No.2, Geneva: UNRISD, 2001.

${ }^{21}$ Naila Kabeer, The Power to Choose London: Verso, 2000.

${ }^{22}$ Oxfam, Trading away our rights: women working in global supplya chains, Oxford: Oxfam International, 2004.

${ }^{23}$ Oxfam, Tax Havens - Releasing the Hidden Billions for Poverty Eradication, Oxfam GB Policy Paper, 2000; Christian Aid, Death and taxes: The true toll of tax dodging, London: Christian Aid, 2008; Christian Aid, False profits: robbing the poor to keep the rich tax free, London: Christian Aid, 2009; Action Aid, Hole in the Pocket: Why Unpaid Taxes are the Missing Link in Development Finance Briefing Paper November London: Action Aid, 2008.

${ }^{24}$ Mick Moore, 'How does taxation affect the quality of governance?' IDS Working Paper 280, 2007.; Mick Moore, M. and O.H. Fjeldstad, 'Revenue authorities and public authority in Sub-Saharan Africa', Journal of Modern African Studies 47(1) 2009.

${ }^{25}$ OECD, 2010, Co-Chairs' Statement, Joint Meeting on Tax and Development between the Committee on Fiscal Affairts (CFA) and the Development Assistance Committee, 27 January.

${ }^{26}$ Palan, R. 2002. 'Tax havens and the commercialisation of sovereignty', International Organisation 56(1): 151-177.

${ }^{27}$ Reuven S. Avi-Yonah, "Corporate Social Responsibility and Strategic Tax Behavior" (December 2006). University of Michigan Law School. Public Law and Legal Theory Working Paper No. 69, 2006, p.13.

${ }^{28} \mathrm{C}$ Fuest \& N Riedel, Tax evasion, tax avoidance and tax expenditures in developing countries: A review of the literature, Said Business School, Oxford University, Report prepared for the UK Department for International Development, 2009, p.1.

${ }^{29}$ Palan, Tax Havens

${ }^{30}$ It is ironic that at the same time that companies have increasingly emphasized their social responsibility through the adoption of codes of conduct and the publication of CSR reports, there has also been a growing reliance of complex strategies to limit corporate tax liabilities.

${ }^{31}$ There is a growing literature on tax havens and the role that they play. See of example R. Palan, R. Murphy and C. Chavagneux, Tax Havens: How Globalization Really Works, Ithaca and London: Cornell University Press, 2010, J. G. Gravelle, Tax havens: International Tax Avoidance and Evasion, Washington DC: Congressional Research Services, CRS Report for Congress R40623, 2009; Norwegian Government Commissiion on Capital Flight from Poor Countries, Tax Havens and Development: status, analyses and measures, Preliminary Report, June 2009.

${ }^{32}$ Quoted in Benari, Tricky Tax: Two tax avoidance schemes explained, mimeo, 2009, p.4.

${ }^{33}$ HMRC, International Tax Handbook - ITH 103 International Tax Planning: Avoidance in International Context quoted in J. Frecknall Hughes and K. Glaister, Taxation and Corporate Social Responsibility: Evidence from UK firms, presentation to the ESRC Seminar Series, Seminar 2: Is Corporate Taxation Practice a CSR Issue?, 25 March 2009, Slide 15. 
${ }^{34}$ Tax Justice Network, 2005, Tax Us if You can, London: Tax Justice Network Briefing Paper, p.66.

${ }^{35}$ The Guardian, 'Tax glossary', http://www.guardian.co.uk/business/2009/feb/01/tax-gap accessed February 11 th 2009.

${ }^{36}$ A Hollingshead, A. (2010), The Implied Tax Revenue Loss from Trade Mispricing, Washington, Global Financial Integrity; Fuest and Riedel, Tax evasion: Review of Literature.

${ }^{37}$ Fuest and Riedel, Tax evasion: Review of Literature, C. Fuest and N. Riedel, 'Tax Evasion and Tax Avoidance: The Role of International Profit Shifting' in P. Reuter (ed.), Draining Development? Conrolling Flows of Illicit Funds from Developing Countries, Washington DC: World Bank; 2012; C. Leite, 'The Role of Transfer Pricing in Illicit Flows' in Reuter (ed.), Draining Development?:

$V$. Nitsch, 'Trade Mispricing and Illicit Flows' in Reuter (ed.), Draining Development?

38 Fuest and Riedel, Tax evasion: Review of Literature, p.VI.

${ }^{39}$ R. Murphy, 'Accounting for the Missing Billions' in Reuter (ed.), Draining Development?; A. Cobham, 'Tax Havens and Illicit

Flows' in Reuter (ed.), Draining Development?

${ }^{40}$ Gravelle, Tax Havens

${ }^{41}$ TUC, The Missing Billions, The UK Tax Gap, London: TUC Publications, 2008.

${ }^{42}$ HMRC have a lower estimate of tax avoidance of $£ 5-7$ billion. See A Seeley, Tax Avoidance: A General Anti-Avoidance Rule,

House of Commons Library, Standard Note SN06265, 2012.

${ }^{43}$ Benari, Tricky Tax, p.4

${ }^{44}$ For a more detailed breakdown of the different ways in which companies reduce their tax bills, see Tax Justice Network, Closing the Floodgates: Collecting tax to pay for development, Report prepared for the Norwegian Ministry of Foreign Affairs, 2007, Ch.4 and Gravelle, Tax Havens.

${ }^{45}$ L.Eden, 'Transfer Price Manipulation' in Reuter (ed.), Draining Development? p.206)

${ }^{46}$ Peter Dicken, Global Shift: Mapping the Changing Contours of the World Economy London: Sage, 2011, p.20.

${ }^{47}$ For a review of these studies, see Eden, Transfer Price

${ }^{48}$ In 2006 Glaxo Smith Kline agreed to pay \$3.1 billion to the US tax authorities in order to settle a long running transfer pricing dispute. For other examples, see P. Sikka and H. Willmott, 'The Dark Side of Transfer Pricing: its role in tax avoidance and wealth retentiveness', Critical Perspectives on Accounting, Vol. 21,No. 4, 2010, pp. 342-356.

${ }^{49}$ Sikka and Willmott, Dark Side, p.352

${ }^{50}$ C.Vaitsos, Inter-Country Income Distribution and Transnational Enterprises, Oxford: Clarendon Press, 1974)

${ }^{51}$ R. Jenkins, Transnational Corporations and Uneven Development, London: Methuen, 1987, p114-120)

${ }^{52}$ Eden, Transfer Price, pp.224-117)

${ }^{53}$ F. Lawrence, 'Argentina accuses world's largest grain traders of huge tax evasion' The Guardian, 1/6/11.

${ }_{55}^{54}$ A. Hollingshead, The Implied Tax Revenue Loss from Trade Mispricing, Washington DC: Global Financial Integrity, 2010.

${ }^{55}$ H.Grubert, 'Intangible Icome, Intercompany Transactions, Income Shifting and the Choice of Locations', National Tax Journal, Vol.56, March 2003, Part II, pp.221-242 quoted in Gravelle, Tax Havens, p.8

${ }^{56}$ I. Griffiths and F. Lawrence, 'Bananas to UK via the Channel islands? It pays for tax reasons' The Guardian, 6/11/07, pp.6-7.

57 'Offshore Drift'. The Guardian, 3/2/09, pp.14-15.

${ }^{58}$ Action Aid, Calling Time: Why SABMiller Should Stop Dodging Taxes in Africa, London: Action Aid, 2012

${ }^{59}$ Action Aid, Sweet Nothings; The human cost of a British sugar giant avoiding taxes in Southern Africa, London: Action Aid, 2013.

60 'Low-tax, low-cost flight to Dublin' The Guardian, 10/2/09, pp.12-13

61 'From the high street to a tax haven', The Guardian, 9/2/09, pp16-17.

${ }^{62}$ Benari, Tricky Tax

${ }^{63}$ 'Going Dutch', The Guardian, 2/2/09, pp.16-17

${ }^{64}$ Tax Justice Network, Closing the floodgates.

${ }^{65}$ This is sometimes referred to as "earnings stripping" (Gravelle, Tax Havens)

${ }^{66}$ M.Riesco, G.Lagos and M.Lima, The 2pay Your Taxes" Debate: Perspectives on Corporate Taxation and Social Responsibility in the Chilean Mining Industry, Technology Business and Society Paper 1, Geneva: UNRISD, 2005, pp.14-15)

${ }^{67}$ Action Aid, Calling Time.

${ }^{68}$ Starbuck's declared losses in the UK on sales of $£ 1.2$ billion over the past three years. It was claimed that the UK operation was able to avoid declaring profits in the UK through paying a 6\% royalty fee to its European HQ in Amsterdam for use of its "intellectual property", payments for imported coffee beans from a Starbuck's Coffe Trading Co. in Switzerland, and through high interest payments (at LIBOR $+4 \%$ ) on intra-company loans. Bergen, T., 2012, Special Report: How Starbucks avoids UK taxes, Reuters.

${ }^{69}$ C. Azémar, International Corporate Taxation and US Multinationals' Behaviour: An Integrated Approach, University of Glasgow, Department of Economics Discussion Paper, August 2008 finds evidence that countries with a low quality of law enforcement tend to have more difficulty in implementing anti-tax avoidance measures such as "thin capitalization" rules or arm's length pricing (quoted in Fuest and Riedel, Tax Evasion: Role of International Profit Sharing, p.121.

${ }^{70}$ John Christensen and Richard Murphy 'The Social Irresponsibility of Corporate Tax Avoidance: Taking CSR to the bottom line', Development, 47(3), 2004, pp. 37-44. Francis Weyzig 'Political and Economic Arguments for Corporate Social Responsibility: Analysis and a Proposition Regarding the CSR Agenda', Journal of Business Ethics 86 (4), 2009, pp. 417-428; Mihir Desai \& Dhammika Dharmapala, 'CSR and Taxation: The Missing Link', 2006 http://www.people.hbs.edu/mdesai/D+D BSR.pdf; Judith Freedman, 'Tax And Corporate Responsibility', Tax Journal, 695 (2) 2003.

${ }^{71}$ V. Houlder, 'The tax avoidance story as a morality tale' Financial Times, 22/7/04, p.7 quoted in A.Muller and A. Kolk, 'Reponsible Tax as Corporate Social Responisbility: The Case of Multinational Enterprises and Effective Tax in India, Business and Society, forthcoming.

${ }^{72}$ Indeed connections between corporate strategies in these parallel areas have been made. One newspaper commented: 'The practice of only paying tax in the lowest charging country in which companies operate is mirrored in other aspects of their operations such as 
labour rights and environmental law where they will move around to operate in the least regulated domain in order to maximise profits'(The Morning Star $13^{\text {th }}$ December 2012, p.12).

${ }^{73} \mathrm{http} / / / \mathrm{www}$.unicef.org.uk/enough-food-for-everyone-if/enough-food-for-everyone-if-the-issues/ accessed 13 February 2013.

${ }^{74}$ The Guardian ran a series of articles on The Tax Gap in February 2009). See also Daily Mail, The Great Tax Heist, 17 December 2010.

${ }^{75}$ There is on-going discussion for example about a code of conduct on international tax cooperation governing the sharing of information between tax authorities.

${ }^{76}$ BBC News, 'George Osbome'snew plans to tackle tax avoidance', 27 March 2012 http://www.bbc.co.uk/news/business-17525977 accessed 19th December 2012.

${ }^{77}$ The Daily Telegraph, 'Davos 2013: David Cameron calls measures to tackle tax avoidance',24 January 2013, http://www.telegraph.co.uk/finance/financetopics/davos/9823032/Davos-2013-David-Cameron-calls-measures-to-tackle-taxavoidance.html accessed 13 February 2013.

${ }^{78}$ For an interesting discussion of the implications of different views of the corporation for CSR and strategic tax behaviour, see AviYonah, Strategic Tax.

79 'CSR', The Guardian, February $14^{\text {th }}$ 2009:41. Barclays has recently announced the closure of its Structured Capital Markets unit which was reported to have contributed $£ 1$ billion a year to the bank's profits through its tax avoidance schemes. F. Lawrence, 'Barclays secret tax avoidance factory that made $£ 1$ billion profit a year disbanded' The Guardian,11 February 2013. http://www.guardian.co.uk/business/2013/feb/11/barclays-investment-banking-tax-avoidance, accessed 13 February 2013.

${ }^{80}$ For a discussion of supply-chain ethics see Stephanie Barrientos \& Catherine Dolan (eds), Ethical Sourcing in the Global Food System, London: Earthscan, 2006.

${ }^{81}$ P. Sikka, 'Smoke and Mirrors: Corporate social responsibility and tax avoidance', Accounting Forum, 34, 2010, pp.153-168.

${ }^{82}$ John Elkington, 'The triple bottom line for twenty-first century business' in J Mitchell Companies in a World of Conflict London: RIIA, 1998, pp.32-61.

${ }^{83}$ Sustainability, Taxing issues: Responsible business and tax, London: Sustainability, 2006.

${ }^{84}$ David Williams, Tax and Corporate Social Responsibility, KPMG Tax Business School Discussion Paper, 2007.

${ }^{85}$ Daily Mail, 'It's called capitalism': Google boss says he is 'proud' of the company's multi-million pound tax avoidance scheme', December $13^{\text {th }}$ 2012. http://www.dailymail.co.uk/news/article-2247321/Google-boss-Eric-Schmidt-says-proud-companys-multimillion-pound-tax-avoidance-scheme.html Accessed 19th December 2012.

${ }^{86}$ See for example R Hardyment, P Truesdale and M Tuffrey, Tax as a Corporate Responsibility Issue: The Implications for Multinationals, London: Corporate Citizenship, 2011.

${ }^{87}$ Other companies whose tax avoidance strategies were put under the spotlight in a series of articles in the Guardian newspaper on the "Tax Gap" in 2009 included the pharmaceutical companies GlaxoSmithKline, AstraZeneca and Shire, PepsiCo (with Walkers Crisps), Vodafone, Lloyds-TSB, Barclays and the WPP advertising group.

${ }^{88}$ Sikka, Smoke and Mirrors

${ }^{89}$ For example Sustainability produced a report Taxing Issues - Responsible Business and Tax in 2006. The Tax Justice Network has also argued strongly that corporate responsibility should include tax issues (TJN, Tax us if you can, Ch.5.1)

${ }^{90}$ OECD, Codes of Corporate Conduct - An Expanded Review of their Contents, Paris: IECD Working Party of the Trade Committee, TD/TC/WP(99)56/FINAL, 2000, p.16)

${ }^{91}$ M. Kaptein, 'Business Codes of Multinational Firms: What Do They Say?' Journal of Business Ethics, 50, 2004, Table V)

${ }^{92}$ L. Preuss, 'Tax avoidance and corporate social responsibility: you can’t do both, or can you?' Corporate Governance, 10(4), 2010, p.371)

${ }_{93}$ It is ironic that the first two of these companies featured in the Guardian 's "Tax Gap" series of articles.

${ }^{94}$ Diageo, Corporate Citizenship Report, 2008, p.28.

${ }^{95}$ WPP, Corporate Responsibility Report, 2008/2009.

${ }^{96}$ Vodafone Group, Tax Code of Conduct.

${ }^{97}$ Interestingly the last part of this statement referring to minimizing tax liabilities has been dropped in the most recent version of the Unilever code (www.unilever.com/sustsinability/economic/tax).

${ }_{98} \mathrm{http} / / / \mathrm{www}$.unilever.com/sustainable-living/betterlivelihoods/tax/ Accessed $13^{\text {th }}$ January 2013.

${ }_{99}^{9}$ Leonard J. Weber 'Citizenship and Democracy: The Ethics of Corporate Lobbying', Business Ethics Quarterly, 6(2), 1996, pp. 253259.

${ }^{100}$ Newell, 'Managing multinationals'. 